\title{
Studi Perbandingan Komposisi Asam Lemak Daging Ikan Sidat (Anguilla marmorata (Q.) Gaimard) Fase Yellow Eel Dari Sungai Palu Dan Danau Poso
}

\section{(Comparative Study of Fatty Acid Composition of Sidat Fish Meat (Anguilla marmorata (Q.) Gaimard) Yellow Eel Phase From Palu River and Poso Lake)}

\author{
Jamaluddin $^{I^{*}}$, Putri Amelia ${ }^{I}$, Agustinus Widodo ${ }^{I}$
}

${ }^{1}$ Jurusan Farmasi,Fakultas MIPA, Universitas Tadulako, Palu, Indonesia, 94118

\section{Article Info:}

Received: 12 Maret 2018

in revised form: 28 Maret 2018

Accepted: 30 Maret 2018

Available Online: 30 Maret 2018

\section{Keywords:}

Anguilla marmorata

fatty acids

Palu river

Poso lake

Corresponding Author:

Jamaluddin

Jurusan Farmasi, FMIPA,

Universitas Tadulako

Palu, 94118, Palu,

Indonesia

Mobile : +6281355198799

Email:

jamal_farmasi02@yahoo.co.id

\begin{abstract}
Sidat fish (Anguilla marmorata (Q.) Gaimard) has high nutrition or nutritional advantages such as vitamin $\mathrm{A}$, vitamin $\mathrm{B}$, vitamin $\mathrm{C}$, vitamin $\mathrm{D}$, vitamin $\mathrm{E}$, protein, minerals, and fatty acids that are good for health. This study aims to determine the fatty acid level and to compare fatty acid composition of sidat fish meat (yellow eel phase) from Palu river and Poso lake. This research was done by gas chromatography method where fat extract was converted into fatty acid methyl ester. The result of fatty acid analysis of sidat fish meat (yellow eel phase) from Palu river and Poso lake showed saturated fatty acid content of $2.766 \mathrm{~g} / 100 \mathrm{~g}$ and 0.275 $\mathrm{g} / 100 \mathrm{~g}$; monounsaturated fatty acids of $4.029 \mathrm{~g} / 100 \mathrm{~g}$ and $0.276 \mathrm{~g} / 100 \mathrm{~g}$; and polyunsaturated fatty acids of $0.541 \mathrm{~g} / 100 \mathrm{~g}$ and $0.102 \mathrm{~g} / 100 \mathrm{~g}$, respectively. There was statistically different $(\mathrm{p}<0.05)$ of fatty acid composition and content between Palu river and Poso lake. The fatty acid compositions of sidat fish meat (yellow eel phase) from Palu river are 23 species, while from Poso lake are18 species. Fatty acids found in Palu river and not found in Poso lake are heneicosanoic acid, miristoleic acid, Cis-10-pentadecenoate, gamma linoleic acid, and Cis-11,14,17eicosatrienoic.
\end{abstract}




\begin{abstract}
ABSTRAK
Ikan sidat (Anguilla marmorata (Q.) Gaimard) memiliki keunggulan gizi atau nutrisi yang tinggi seperti vitamin $\mathrm{A}$, vitamin $\mathrm{B}$, vitamin $\mathrm{C}$, vitamin $\mathrm{D}$, vitamin $\mathrm{E}$, protein, mineral, dan asam lemak yang baik bagi kesehatan. Penelitian ini bertujuan untuk menentukan kadar asam lemak dan membandingkan komposisi asam lemak dari ikan sidat fase yellow eel asal sungai Palu dan danau Poso. Penelitian ini menggunakan metode kromatografi gas dengan mengubah ekstrak lemak menjadi metil ester asam lemak. Hasil analisis komposisi asam lemak daging ikan sidat (Anguilla marmorata (Q.) Gaimard) fase yellow eel asal sungai Palu dan Danau Poso menunjukan kadar asam lemak jenuh masing-masing $2.766 \mathrm{~g} / 100 \mathrm{~g}$ dan $0.275 \mathrm{~g} / 100 \mathrm{~g}$; asam lemak tak jenuh tunggal $4.029 \mathrm{~g} / 100 \mathrm{~g}$ dan $0.276 \mathrm{~g} / 100 \mathrm{~g}$; dan asam lemak tak jenuh ganda $0.541 \mathrm{~g} / 100 \mathrm{~g}$ dan $0.102 \mathrm{~g} / 100 \mathrm{~g}$. Terdapat perbedaan secara statistik $(\mathrm{p}<0.05)$ komposisi dan kadar asam lemak antara daging ikan sidat fase yellow eel asal sungai Palu dan danau Poso. Komposisi asam lemak ikan sidat fase yellow eel asal sungai Palu dan danau Poso masing-masing adalah 23 dan 18 jenis. Asam lemak yang ditemukan pada daging ikan sidat sungai Palu dan tidak ditemukan pada ikan sidat danau Poso adalah asam heneikosenoat, asam miristoleat, Cis-10-pentadekanoat, asam gamma linoleat, dan Cis-11,14,17-eikosatrinoat.
\end{abstract}

Kata Kunci : Anguilla marmorata, asam lemak, sungai Palu, danau Poso

\section{PENDAHULUAN}

Ikan air tawar di Sulawesi tercacat sebanyak 62 jenis dan 52 di antaranya merupakan jenis ikan endemik. Salah satu jenis ikan endemik yang berada di Sulawesi adalah ikan sidat (Anguilla Marmorata (Q.) Gaimard). Populasi ikan sidat terdapat di sungai-sungai Sulawesi Tengah, danau Poso, dan muara sungai teluk Palu. Sungai-sungai di Sulawesi Tengah umumnya terdapat populasi ikan sidat (Ndobe, 2010). Ada 5 jenis ikan sidat yang terdapat di danau Poso yaitu Anguilla Marmorata (Q.) Gaimard, Anguilla celebensis, Anguilla interioris, Anguilla bicolor paciic, dan Anguilla borneoensis (McKinnon, 2006).

Ikan sidat merupakan jenis ikan yang mempunyai siklusi hidup bersifat katadromus, yaitu berada di perairan darat dari mulai fase larva hingga mencapai dewasa dan akan beruaya (bermigrasi) ke perairan laut untuk memijah (Suryono, 2013). Siklus ikan sidat terdapat beberapa tahapan, yaitu telur, larva (leptochepalus), glass eel ,elver, yellow eel (panjang 300-600 $\mathrm{mm}$ ) atau sering disebut tingkat stadia fingerling dengan mendiami perairan tawar seperti sungai, waduk, danau, rawa kemudian tumbuh menjadi sidat dewasa silver eel (panjang > $600 \mathrm{~mm}$ ) (Husnah, 2008).

Ikan sidat memiliki keunggulan gizi atau nutrisi yang tinggi seperti vitamin A, EPA (Eikosapentanoat acid) dan DHA (Dokosaheksanoat acid) (Sudaryono, 2013). Asam lemak merupakan bagian dari minyak lemak yang bermanfaat sebagai pelarut obat, kosmetik maupun bahan tambahan (Eni,
2001). Asam lemak dibagi menjadi dua golongan yaitu asam lemak jenuh dan asam lemak tak jenuh, asam lemak jenuh merupakan asam lemak yang normal yang dibuat oleh tubuh yang bermanfaat untuk melawan virus, bakteri, dan protozoa serta mendukung sistem kekebalan tubuh (Doyle, 1997). Sedangkan asam lemak tak jenuh, bermanfaat untuk membantu tumbuh kembang otak, perkembangan indra penglihatan, dan sistem kekebalan tubuh (Panagan, 2012).

Beberapa penelitian terkait analisis kandungan asam lemak ikan air tawar telah dilakukan. Salah satunya adalah penelitian yang dilakukan oleh Hafiludin (2015) terhadap kandungan gizi ikan bandeng yang berasal dari habitat yang berbeda, yang hasilnya didapatkan komposisi asam lemak ikan bandeng dari air tawar Kabupaten Lamongan, yaitu miristat $(0,3855 \%)$, palmitat $(39,372 \%)$, stearat $(3,258 \%)$, oleat $(32,868 \%)$, linoleat $(4,672 \%)$. Sedangkan komposisi asam lemak ikan bandeng dari air payau Kabupaten Bangkalan, yaitu miristat $(4,037 \%)$, palmitat $(41,484 \%)$, stearat $(4,012 \%)$, oleat $(31,399 \%)$, linoleat $(6,041 \%)$. Hasil penelitian tersebut menunjukkan bahwa habitat yang berbeda berpengaruh terhadap kadar asam lemak ikan.

Selama ini penelitian ikan sidat cenderung terfokus pada sungai dan danau Poso, sehingga ketersediaan data di sungai atau danau lainnya, termasuk sungai Palu masih sangat kurang. Oleh karena itu pengujian komposisi asam lemak ikan sidat fase yellow eel asal sungai Palu dan danau Poso 
penting dilakukan untuk melengkapi data kandungan asam lemak ikan sidat yang ada di Sulawesi.

\section{METODE PENELITIAN}

\section{Alat}

Kromatografi gas (Shimadzu QP 2010S) yang dilengkapi detektor FID (Flame Ionization Detector), oven, satu set alat sokletasi, eksikator, neraca analitik, blender, penangas air, dan vortex.

\section{Bahan}

Ikan sidat (Anguilla marmorata (Q.) Gaimard), Natrium hidroksida $(\mathrm{NaOH})$, Methanol, Boron trifluorida $\left(\mathrm{BF}_{3}\right)$, Natrium klorida $(\mathrm{NaCl})$, nheksan $\left(\mathrm{C}_{6} \mathrm{H}_{14}\right)$, dan larutan standar FAME (Fatty Acid Methyl Ester) Mix.

\section{Metode}

\section{Preparasi Sampel}

Ikan sidat diambil dari sungai Palu dan danau Poso. Ikan dimasukkan ke dalam wadah sterofoam yang telah berisi es batu sebelum dilakukan pengolahan lebih lanjut. Sampel dicuci bersih dan dikeluarkan isi perut, kepala, ekor, dan tulangnya. Sampel dipotong kecil-kecil dan dikeringkan di oven suhu $60^{\circ} \mathrm{C}$ selama 24 jam, selanjutnya sampel diblender hingga menjadi serbuk, lalu disimpan dalam suhu ruang $\left(20-25^{\circ} \mathrm{C}\right)$ dalam wadah stainless steel (Pratama R. dkk., 2011).

\section{Kadar Lemak Total}

Ditimbang masing-masing $10 \mathrm{~g}$ sampel kering ikan sidat fase yellow eel asal sungai Palu dan danau Poso, kemudian dimasukkan ke dalam selongsong kertas dan dikeringkan dalam oven selama \pm 1 jam pada suhu $70^{\circ} \mathrm{C}$. Sampel yang ada dalam selongsong kertas diekstraksi dengan metode sokletasi menggunakan pelarut n-heksan selama 5 jam. Pelarut $n$-heksan yang telah disuling dikeringkan pada suhu $105^{\circ} \mathrm{C}$, lalu ekstrak minyak didinginkan dalam eksikator sampai ekstrak minyak kental memiliki bobot yang tetap (Pratama R. dkk., 2011)

\section{Pengujian Sampel}

Sampel yang diperoleh dari tahap sebelumnya diderivatisasi menjadi metil ester asam lemak, yang memiliki sifat yang mudah menguap (volatile) sehingga dapat disuntikkan ke dalam kromatografi gas. Hasil ekstraksi minyak ditimbang $0,03 \mathrm{~g}$ dan ditambahkan $2 \mathrm{ml} \mathrm{NaOH} 0,5 \mathrm{M}$, lalu dipanasakan dalam penangas air selama 20 menit suhu $100^{\circ} \mathrm{C}$. Dinginkan dan kocok sampai suhu $30^{\circ} \mathrm{C}$, setelah itu ditambahkan $2 \mathrm{ml} \mathrm{NaCl}$ jenuh, lalu divorteks selama 2 menit dan ditambahkan n-heksan $10 \mathrm{ml}$, kemudan divortek kembali selama 2 menit. Selanjutnya didiamkan pada suhu ruangan, ambil lapisan heksan-metil ester, pindahkan ke dalam labu ukur $10 \mathrm{ml}$ lalu encerkan dan cukupkan dengan nheksan (Pratama R. dkk., 2011).

\section{Analisis Data}

Data kadar lemak total dan asam lemak didapatkan dengan menggunakan rumus:

$$
\begin{aligned}
& \text { Lemak Total }=\frac{C-A}{B} X 100 \% \\
& \qquad \begin{aligned}
\mathrm{A}= & \text { Bobot labu lemak kosong }(\mathrm{g}) \\
\mathrm{B}= & \text { Bobot sampel }(\mathrm{g}) \\
\mathrm{C}= & \text { Bobot tetap labu lemak }+ \text { sampel setelah } \\
& \text { pemanasan }(\mathrm{g})
\end{aligned}
\end{aligned}
$$

Asam lemak $=\frac{\text { Luas area asam lemak }}{\text { Luas area total asam lemak }} X$ Lemak total

Data selanjutnya dianalisis menggunakan uji statistik parametrik, dimana uji hipotesis menggunakan uji-t tidak berpasangan.

\section{HASIL DAN PEMBAHASAN Kandungan Lemak Total}

Hasil analisis kandungan lemak total dari daging ikan sidat (Anguilla marmorata (Q.) Gaimard) yang diambil dari Sungai Palu dan Danau Poso, sangat berbeda. Daging ikan sidat sungai Palu memiliki kandungan lemak total lebih banyak dibandingkan dengan daging ikan sidat yang berasal dari danau Poso (Gambar 1).

Analisis komposisi asam lemak pada daging ikan sidat asal sungai Palu dan danau Poso menunjukkan adanya kandungan asam lemak jenuh (Saturated Fatty Acid/SAFA), asam lemak tak jenuh tunggal (Monounsaturated Fatty Acid/MUFA), dan asam lemak tak jenuh jamak (Polyunsaturated Fatty Acid/PUFA).

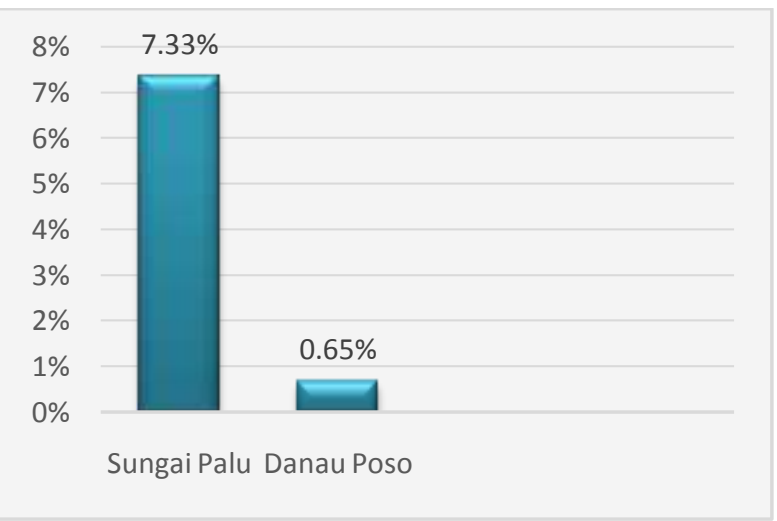

Gambar 1. Kandungan Lemak Total 


\section{Kadar Asam Lemak Jenuh Daging Ikan Sidat Asal Sungai Palu dan Danau Poso}

Hasil pengujian asam lemak jenuh daging ikan sidat asal sungai Palu menunjukkan adanya 9 jenis asam lemak dengan kadar yang beragam, dimana asam lemak yang dominan yaitu asam palmitat, asam stearat, asam miristat (Gambar 2). Adapun pada daging ikan sidat asal danau Poso menunjukkan adanya 8 jenis asam lemak dengan kadar yang beragam, dimana asam lemak yang dominan yaitu asam palmitat, asam stearat, asam miristat (Gambar 3).

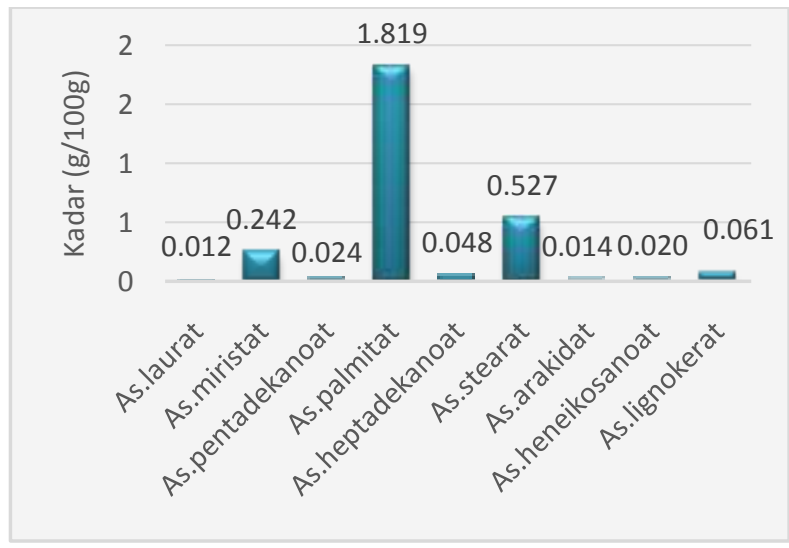

Gambar 2. Kadar Asam Lemak Jenuh Daging Ikan Sidat Sungai Palu

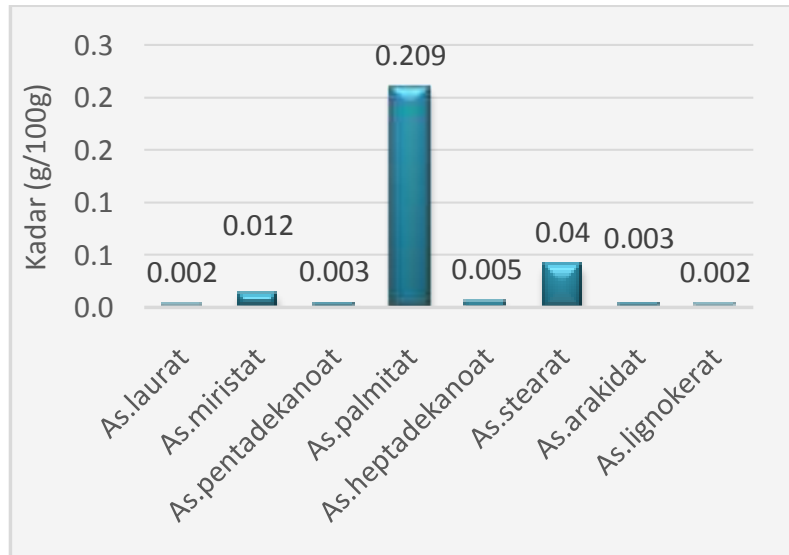

Gambar 3. Kadar Asam Lemak Jenuh Daging Ikan Sidat Danau Poso

\section{Kadar Asam Lemak Tak Jenuh Tunggal Daging} Ikan Sidat Asal Sungai Palu dan Danau Poso

Hasil pengujian asam lemak tak jenuh tunggal daging ikan sidat asal sungai Palu menunjukkan adanya 6 jenis asam lemak dengan kadar yang beragam, dimana asam lemak tak jenuh tunggal yang dominan yaitu asam oleat dan asam palmitoleat (Gambar 4). Adapun pada daging ikan sidat asal danau Poso menunjukkan adanya 4 jenis asam lemak dengan kadar yang beragam, dimana asam lemak yang dominan yaitu asam oleat dan asam palmitoleat (Gambar 5).

Hasil pengujian asam lemak tak jenuh tunggal (Gambar 3 dan 6) menunjukan bahwa asam lemak tak jenuh tunggal (Mono Unsaturated Fatty Acid/MUFA) pada daging ikan sidat sungai Palu dan danau Poso fase yellow eel ditemukan dengan jenis yang beragam dan konsentrasi yang bervariasi. Asam lemak tak jenuh tunggal yang ditemukan pada kedua sampel tersebut didominasi oleh asam oleat. Asam oleat dikenal juga sebagai asam lemak omega-9, asam lemak ini memiliki daya perlindungan tubuh yang mampu menurunkan kadar kolestrol LDL (Low Density Lipoprotein), dan meningkatkan kadar kolestrol HDL (High Density Lipoprotein) (Khomsan, 2004).

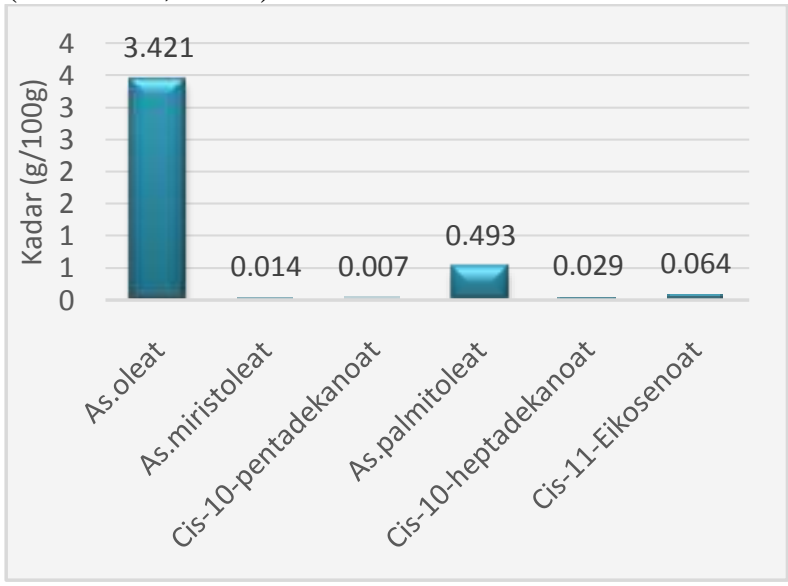

Gambar 4. Kadar Asam Lemak Tak Jenuh Tunggal Daging Ikan Sidat Sungai Palu

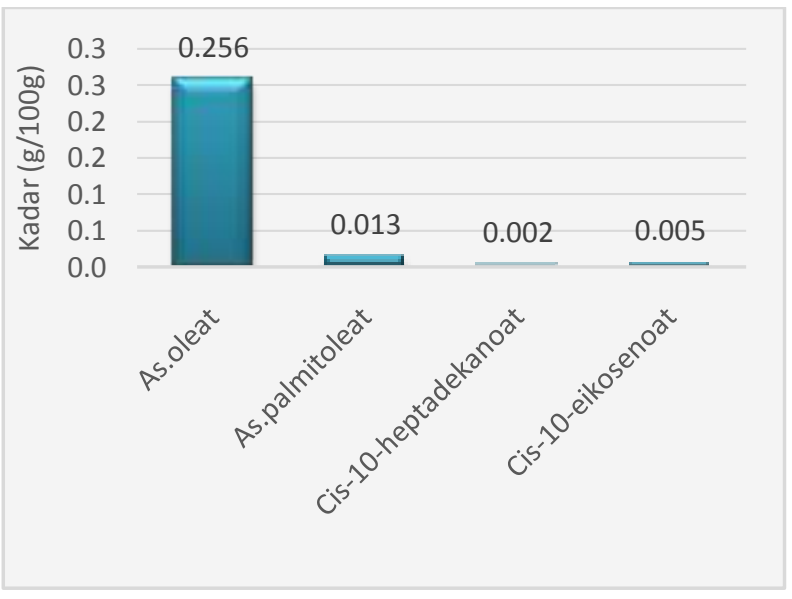

Gambar 5 . Kadar Asam Lemak Tak Jenuh Tunggal Daging Ikan Sidat Danau Poso 


\section{Kadar Asam Lemak Tak Jenuh Jamak Daging Ikan Sidat Asal Sungai Palu dan Danau Poso}

Hasil pengujian asam lemak tak jenuh jamak daging ikan sidat asal sungai Palu menunjukkan adanya 8 jenis asam lemak dengan kadar yang beragam, dimana asam lemak yang dominan yaitu asam dokosaheksanoat dan asam linoleat (Gambar 6). Adapun pada daging ikan sidat asal danau Poso menunjukkan adanya 6 jenis asm lemak dengan kadar yang beragam, dimana asam lemak yang dominan yaitu asam oleat dan asam palmitoleat (Gambar 7).

Ikan sidat sungai Palu dan danau Poso mengandung asam lemak tak jenuh jamak. Asam lemak tak jenuh jamak (Poly Unsaturated Fatty Acid) yang disingkat PUFA, diantaranya Omega-3 dan Omega-6 yang merupakan asam lemak esensial yang tidak dapat disintesis oleh tubuh serta memiliki manfaat yang besar bagi kesehatan. PUFA (asam lemak linoleat dan asam linolenat) berperan penting dalam transport dan metabolisme lemak, fungsi imun, mempertahankan fungsi dan integritas membran sel. Turunan asam lemak yang berasal dari asam lemak esensial adalah asam arakidonat dari asam linoleat (omega-6), EPA (Eikosapentanoat Acid), dan DHA (Dokosaheksanoat Acid) dari asam linolenat (Omega3) (Almatsier, 2009).

Asam lemak tak jenuh jamak yang dominan pada kedua sampel yaitu asam lemak dokosaheksanoat dan asam lemak linoleat. Turunan dari asam lemak esensial adalah asam arakidonat dari asam linoleat, asam lemak esensial merupakan prekursor sekelompok senyawa yang mirip hormon seperti prostaglandin, prostasiklin, tromboksan, dan leukotriene. Senyawa-senyawa ini mengatur tekanan darah, denyut jantung, fungsi kekebalan, rangsangan sistem saraf, kontraksi otot serta penyembuhan luka (Sartika, 2008).

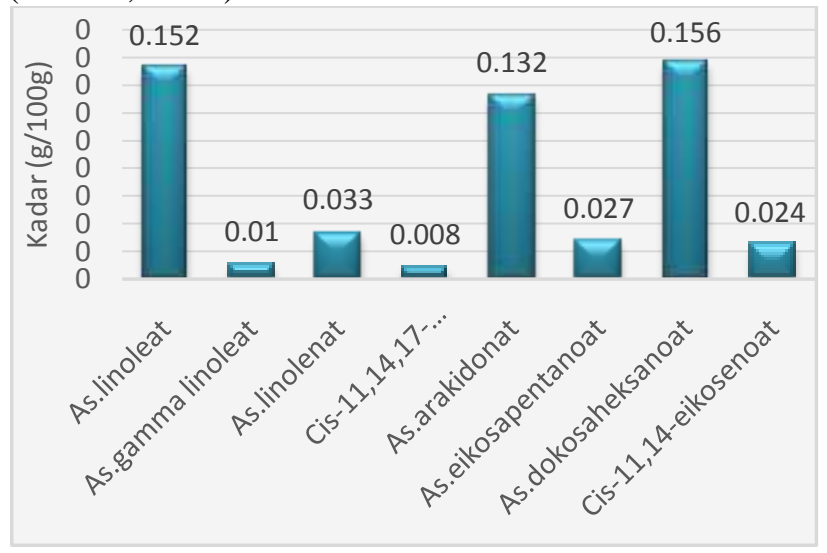

Gambar 6. Kadar Asam Lemak Tak Jenuh Jamak Daging Ikan Sidat Sungai Palu

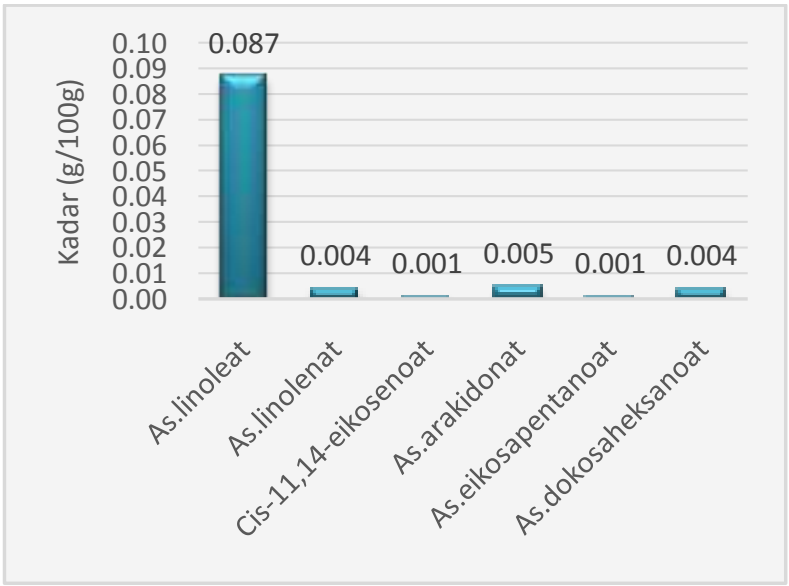

Gambar 7. Kadar Asam Lemak Tak Jenuh Jamak Daging Ikan Sidat Danau Poso

Hasil analisis data secara statistik menggunakan uji-t tidak berpasangan dengan nilai signifikan $\mathrm{p}<0,05$. Dari 17 jenis asam lemak yang terdapat pada daging ikan sidat sungai Palu dan danau Poso terdapat perbedaan kadar yang signifikan antara 16 jenis asam lemak tersebut yaitu asam laurat, asam miristat, asam pentadekanoat, asam palmitat, asam heptadekanoat, cis-10-heptadekanoat, asam oleat, asam linoleat, asam arakidat, cis-11-eikosenoat, asam arakidonat, cis-11,14-eikosenoat, asam lignokerat, asam eikosapentanoat, asam dokosaheksanoat, dan asam linolenat; dan tidak terdapat perbedaan yang signifikan pada 1 jenis asam lemak, yaitu asam palmitoleat.

\section{KESIMPULAN}

disimpulkan:

Berdasarkan hasil penelitian, dapat

1. Kadar asam lemak daging ikan Sidat (Anguilla marmorata (Q.) Gaimard) fase yellow eel dari sungai Palu dan danau Poso berturut-turut yaitu asam lemak jenuh $2.766 \mathrm{~g} / 100 \mathrm{~g}$ dan $0.275 \mathrm{~g} / 100 \mathrm{~g}$; asam lemak tak jenuh tunggal $4.029 \mathrm{~g} / 100 \mathrm{~g}$ dan $0.276 \mathrm{~g} / 100 \mathrm{~g}$; dan asam lemak tak jenuh jamak $0.541 \mathrm{~g} / 100 \mathrm{~g}$ dan $0.102 \mathrm{~g} / 100 \mathrm{~g}$.

2. Terdapat perbedaan jumlah komposisi asam lemak ikan sidat fase yellow eel asal sungai Palu dan danau Poso, dimana asam lemak ikan sidat sungai Palu ada 23 jenis dan danau Poso ada 18 jenis.

3. Asam lemak yang ditemukan pada daging ikan sidat sungai Palu dan tidak ditemukan pada ikan sidat danau Poso adalah asam heneikosenoat, asam miristoleat, Cis-10-Pentadekanoat, asam gamma linoleat, dan Cis-11,14,17-Eikosatrinoat. 


\section{UCAPAN TERIMAKASIH}

Penulis ingin mengucapkan terimakasih kepada Lembaga Ilmu Pengetahuan Indonesia (LIPI) Bogor dan PT Angler BioChemblab yang telah membantu untuk menyelesaikan penelitian ini.

\section{DAFTAR PUSTAKA}

Anggraini, D. K. (2015). Fatty acid profile of jelawat fish (Leptobarbus hoevennii) based on different harvesting time. Jurnal Online Mahasiswa (JOM) Bidang Perikanan dan Ilmu Kelautan, 2(2), 1-11.

Sartika, R. A. D. (2008). Pengaruh asam lemak jenuh, tidak jenuh dan asam lemak trans terhadap kesehatan. Kesmas: National Public Health Journal, 2(4), 154-160.

Almatsier, S. (2002). Prinsip dasar ilmu gizi. Gramedia Pustaka Utama.

Doyle, E. (1997). Trans Fatty Acids. New York: Journal of Chemical Education, 74,10301032.

Eni S.R dan Sumarno. (2001). Kandungan Asam Lemak Dalam Biji Durian (Durio zibethinus). Yogyakarta: Majalah Farmasi Indonesia, 12 (2), 65-71.

Hafiludin, H. (2015). Analisis Kandungan Gizi Pada Ikan Bandeng Yang Berasal Dari Habitat Yang Berbeda. Jurnal Kelautan: Indonesian Journal of Marine Science and Technology, 8(1), 37-43.

Husnah, Tahio, H., W., D., Nestitih, A., Oktaviani, A., Nasution, H., S. Sulistiono. (2008). Status Keanekaragaman Hayati Sumber Daya Perikanan Perairan Umum Sulawesi Tengah. Palembang: Badan riset Perikanan Perairan Umum.

Khomsan, A. (2004). Peranan pangan dan gizi untuk kualitas hidup. Gramedia Widiasarana Indonesia, Jakarta.

McKinnon, L. J. (2006). A review of eel biology: Knowledge and gaps. Report to EPA Victoria.

Ndobe, S. (2010). Struktur ukuran glass eel ikan sidat (Anguilla marmorata) di Muara Sungai Palu, kota Palu, Sulawesi Tengah. Media Litbang Sulteng, 3(2).

Panagan, A. T., Yohandini, H., \& Gultom, J. U. (2011). Analisis kualitatif dan kuantitatif asam lemak tak jenuh omega-3 dari minyak ikan patin (Pangasius pangasius) dengan metoda kromatografi gas. Jurnal Penelitian Sains, 14(4).
Pratama, R. I., Awaluddin, M. Y., \& Ishmayana, S. (2011). Komposisi Asam Lemak Ikan Tongkol, Layur, Dan Tenggiri dari Pameungpeuk, Garut. Jurnal Akuatika, 2(2).

Silalahi, J. (2006). Makanan fungsional. Kanisius.

Sudaryono Agung., Sapto, P., Putro, S. (2013). Tinjauan Potensi Pengembangan dan Aplikasi Teknologi Budidaya Sidat. Semarang: Konferensi Akuakultur Indonesia.

Suryono, T., \& Badjoeri, M. (2013). Kualitas Air Pada Uji Pembesaran Larva Ikan Sidat (Anguilla spp.) Dengan Sistem Pemeliharaan Yang Berbeda. LIMNOTEK-Perairan Darat Tropis di Indonesia, 20(2). 